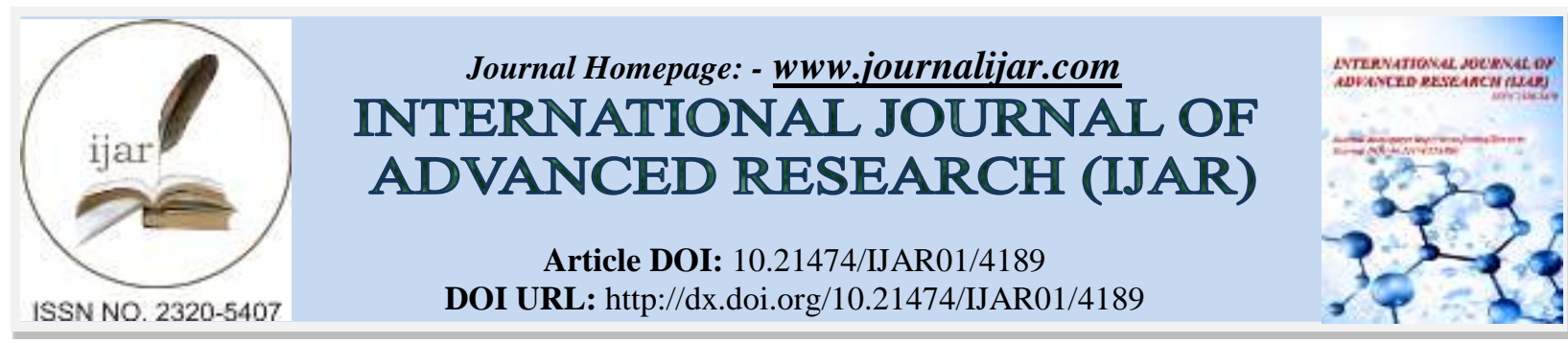

RESEARCH ARTICLE

\title{
TEENAGERS' PREFERENCE TOWARDS BRANDED AND UNBRANDED PRODUCTS: CASE STUDY OF HYDERABAD, PAKISTAN.
}

\author{
Tayyaba Rafique Makhdoom ${ }^{1}$, Dr. Muhammad Nawaz ${ }^{2}$, Dr Mushtaque Ali Jariko ${ }^{3}$, Tania Mushtaque ${ }^{4}$ and \\ Ansar Aalam ${ }^{4}$. \\ 1. Lecturer, Business Administration, University of Sindh Laar Campus Badin. \\ 2. Assistant Professor, Sindh University Laar Campus Badin. \\ 3. Assistant Professor, Business Administration, University of Sindh, Jamshoro, Pakistan \\ 4. Lecturer at Institute of Information and Communication Technology (IICT). \\ 5. BBA student Sindh University Laar Campus Badin
}

\section{Manuscript Info}

Manuscript History

Received: 06 March 2017

Final Accepted: 08 April 2017

Published: May 2017

Key words:-

Brand, young adult, buying decision,

Hyderabad, Pakistan
Abstract

The focus of this research is toward examining preferences and knowledge of teenagers about branded and unbranded products. Data was gathered from 300 students of different public/private schools and colleges of Hyderabad city related to the mature group of 13-19 years old. The main purpose is to know the level of awareness of teens in Hyderabad city and what proportion of branded products are used by teens.

The judgmental probability sampling was used and data was conducted by analyzing software SSPS. The results show that female teenagers have variety seeking and made their choice under the influence of current fashion trends. On the other hand male teens purchased branded products on an occasional basis. The overall results show that teenagers in Hyderabad city are highly aware about branded products. Hence, the companies of branded products should target, particularly on a teen's class by improving quality of products relative to its price

Copy Right, IJAR, 2016,. All rights reserved.

\section{Introduction:-}

Teenagers are one of the key segments to target by various branded products/Unbranded products manufacturers (Lee Taylor and Cosenza, 2002). This study investigated the perception and attitude of young adults toward such products. A brand can be defined as any logo, signature and a sentence that might represent a product (Kotler and Keller 2006). The main reason of selecting teenagers that they have deep information and knowledge about the brand and its preferences because in Hyderabad, the literacy rate of teenagers is low and only teenagers of colleges and schools can easily explain their views about the brand and its preferences.

\section{Objectives:-}

- To know about the preferences and attitudes of teenagers relating to branded and unbranded products in Hyderabad.

- To examine how much proportion of branded and unbranded products are used by teenagers.

- To know the level of awareness about branded products. 


\section{Literature Review:-}

Sahimi Mhtar and Mazhar Abbas, (2014) reported active, variety seeking and informed behavior of teenagers about branded products. However, level of brand consciousness is more in females. Furthermore, Durrani et al, (2015) advocated that advertisement contribute and enhance brand loyalty among young adults. In addition, Martin and Bush, (2000) revealed that brand loyalty depends upon reviews of any particular brand user and in result of reviews people become a user of the product for long term and might spend more on these products.

Teng, Laroche and Huihuang (2007) noted that customer researched for the products before buying them and utilize various criteria in buying decision making. Furthermore, past experience with the product could contribute in customer buying Grewal et al (2017). However, Harradine and Ross (2007) revealed that perception about brands could be varied among parents and their young kids. That's why marketers need to target kids in the early age to develop long term loyalty (Ross, and Harradine, 2004). Moreover, shah (2016) reported that TV advertisement has a vital impact upon buying decisions of the young adults. Likewise, Siddiqui and Singh (2016) reported influence of social media on consumer preference of brand. Khan et al (2016) attempted to develop and validate brand experience consist of 22 variable within the Indian context. However, there is a paucity of research within context of the Sindh about brand preference and awareness among young adults.

\section{Hypotheses:-}

- Teenagers have high brand awareness.

- Teenagers have high preferences toward branded products.

- Female teenagers have more awareness about the brand than male teenagers.

- Teenagers will have low bargaining because they are dependent on their parents.

\section{Conceptual Framework:-}

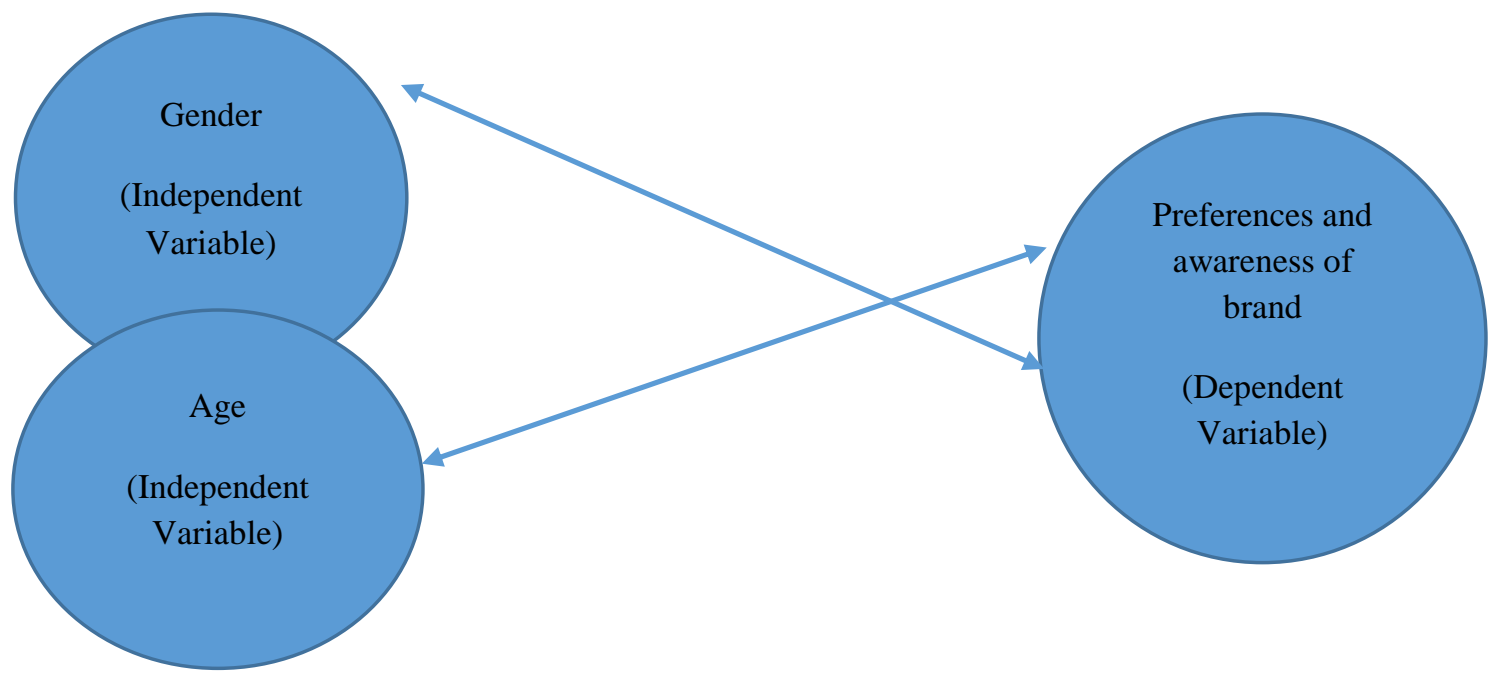

\section{Research Methodology:-}

It is quantitative research in which sample size of 300 respondents selected, studying in different colleges and schools (Ninth to twelfth classes). Out of 300 respondents 151 was male teenagers and 149 female teenagers' ratio $50.3 \%$ and $49.7 \%$ respectively. The students of different colleges and schools of Hyderabad were target population. The closed ended questionnaires were provided and filled by respondents and collected data was entered in computer software (SSPS) for quantitative analysis. Sequentially to find out the results, the judgmental probability sampling was used, 15 items of questions, nominal scale and multiple questions included in the questionnaires. 
Data Analysis:-

\begin{tabular}{|l|l|l|l|l|l|}
\hline \multicolumn{5}{|l|}{ Gender:- } \\
\hline \multicolumn{2}{|l|}{ Gender } & Frequency & Percent & Valid Percent & Cumulative Percent \\
\hline \multirow{3}{*}{} & Male & 151 & 50.3 & 50.3 & 50.3 \\
\cline { 2 - 3 } & Female & 149 & 49.7 & 49.7 & 49.7 \\
\cline { 2 - 3 } & Total & 300 & 100.0 & 100.0 & \\
\hline
\end{tabular}

The table number. 1 shows that the total respondents were 300, by which 151 respondents was male teenagers and 141 was female teenagers. The total percentage was $100 \%$, by which $50.3 \%$ of questionnaires was filled by males' teenagers and $49.7 \%$ of questionnaires was filled by female teenagers. It shows that questionnaires were filled by approximately equal gender, which means it is probable research.

People know about the brand

\begin{tabular}{|c|c|c|c|c|}
\hline Options & Frequency & Percent & Valid Percent & Cumulative Percent \\
\hline Yes & 300 & $100 \%$ & $100 \%$ & $100 \%$ \\
\hline NUMBER & 0 & $0 \%$ & $0 \%$ & $0 \%$ \\
\hline
\end{tabular}

The table number.2 states that the whole population of Hyderabad city had heard about the brand, so it shows that out of 00 respondents, 300 respondents say "yes" and none of them tick the option "no". It means that all respondents clear about branded products.

Purchasing of branded products

\begin{tabular}{|c|c|c|c|c|c|}
\hline \multicolumn{2}{|c|}{ Options } & Frequency & Percent & Valid Percent & Cumulative Percent \\
\hline \multirow{4}{*}{ Valid } & Always & 65 & 21.7 & 21.7 & 21.7 \\
\cline { 2 - 6 } & Sometimes & 200 & 66.7 & 66.7 & 88.3 \\
\cline { 2 - 6 } & Rarely & 23 & 7.7 & 7.7 & 96.0 \\
\cline { 2 - 6 } & Never & 12 & 4.0 & 4.0 & 100.0 \\
\cline { 2 - 6 } & Total & 300 & 100.0 & 100.0 & \\
\hline
\end{tabular}

The table number. 3 states that 65 respondents choose "Always" with $21.7 \%, 200$ respondents had selected the option "Sometimes" with 66.7\%, 23 respondents have selected option "Rarely" with 7.7\% and 12 respondents did not ever buy the branded products which have 4\%. It shows that teenagers of Hyderabad do not purchase branded products on a regular basis, they have just purchase branded products on some events and occasion.

Price sensitive consumer.

\begin{tabular}{|c|c|c|c|c|c|}
\hline \multicolumn{2}{|c|}{ Options } & Frequency & Percent & Valid Percent & Cumulative Percent \\
\hline \multirow{3}{*}{ Valid } & Yes & 205 & 68.3 & 68.3 & 68.3 \\
\cline { 2 - 6 } & No & 95 & 31.7 & 31.7 & 100.0 \\
\cline { 2 - 6 } & Total & 300 & 100.0 & 100.0 & \\
\hline
\end{tabular}

The table number. 4 states that mostly teenagers of Hyderabad city are price sensitive consumer, they mainly focus on price. Out of 300 respondents 205 teenagers declared that "yes" they are price sensitive consumer with $68.3 \%$ while remaining 95 respondents declared that "no" they are not price sensitive consumer and they buy the branded products with no price in mind.

Inspiration from brand ambassadors.

\begin{tabular}{|l|l|l|l|l|l|}
\hline Options & Frequency & Percent & Valid Percent & Cumulative Percent \\
\hline \multirow{5}{*}{ Valid } & Yes & 56 & 18.7 & 18.7 & 18.7 \\
\cline { 2 - 6 } & Sometime & 116 & 38.7 & 38.7 & 57.3 \\
& S & & & & 100.0 \\
\cline { 2 - 6 } & No & 128 & 42.7 & 42.7 & 100.0 \\
\cline { 2 - 6 } & Total & 300 & 100.0 & 10 & \\
\hline
\end{tabular}


The table number. 5 states that out of 300 respondents, 56 teenagers had selected the option "yes" with $18.7 \%, 116$ respondents had selected the option "sometimes" with $38.7 \%$, they buy branded products sometimes by inspiring from brand ambassadors and 128 teenagers had selected option "no" with $42.7 \%$. It clears the image that mostly of teenagers in Hyderabad don't buy the branded products by inspiring from brand ambassadors.

Main focus at the time of buying.

\begin{tabular}{|c|c|c|c|c|c|}
\hline \multicolumn{2}{|l|}{ Options } & Frequency & Percent & Valid Percent & Cumulative Percent \\
\hline \multirow{4}{*}{ Quality } & 223 & 74.3 & 74.3 & 74.3 \\
\cline { 2 - 6 } & Features & 58 & 19.3 & 19.3 & 93.7 \\
\cline { 2 - 6 } & Size/weight & 8 & 2.7 & 2.7 & 96.3 \\
\cline { 2 - 6 } & Price & 11 & 3.7 & 3.7 & 100.0 \\
\cline { 2 - 6 } & Total & 300 & 100.0 & 100.0 & \\
\hline
\end{tabular}

The table number. 6 states that 223 respondents had selected option "quality" with $74.3 \%$, when 58 respondents had selected the option "features" with valid percent of $19.3 \%$, while 8 teenagers had selected the option "size/weight" with $2.7 \%$ and other 11 teenagers had selected the option "price" with $3.7 \%$. It shows that commonly teenagers in Hyderabad focus on quality rather than features, size/weight, price at the time of buying branded products.

Stickiness with same product.

\begin{tabular}{|l|l|l|l|l|l|}
\hline \multicolumn{2}{|c|}{} & Frequency & Percent & Valid Percent & $\begin{array}{l}\text { Cumulative } \\
\text { Percent }\end{array}$ \\
\hline \multirow{2}{*}{} & & & & 32.3 \\
\cline { 2 - 6 } & Yes (in spite of increase in price) & 97 & 32.3 & 32.3 & 80.7 \\
\cline { 2 - 6 } & Up to a certain limit & 145 & 48.3 & 48.3 & 100.0 \\
\cline { 2 - 5 } & Total look for different products & 58 & 19.3 & 19.3 & 100.0 \\
\end{tabular}

The table number.7 states that 97 respondents had selected the option "yes (in spite of increase in price)" with $32.3 \%$, while 145 teenagers had selected the option "up to a certain limit" with $48.3 \%$ and remaining 58 respondents had selected the option "no (I look for other products)". It shows that half population buy the branded products with increase in limited price, if the price increases beyond their limits then they look for other products but third part of population buy the branded products in spite of increase in price.

\section{Bargaining.}

\begin{tabular}{|l|l|l|l|l|l|}
\hline Options & Frequency & Percent & Valid Percent & Cumulative Percent \\
\hline Valid & Yes & 120 & 40.0 & 40.0 & 40.0 \\
\cline { 2 - 6 } & $\begin{array}{l}\text { Sometimes (in case of } \\
\text { highly prized) }\end{array}$ & 115 & 38.3 & 38.3 & 78.3 \\
\cline { 2 - 6 } & No & 65 & 21.7 & 21.7 & 100 \\
\cline { 2 - 6 } & Total & 300 & 100.0 & 100.0 & \\
\hline
\end{tabular}

The table number. 8 shows that out of 300 respondents, 120 respondents bargain at the time of purchasing branded products, 115 respondents bargain when the prize of branded products is too much high than their expectations and 65 respondents don't bargain at the time of purchasing branded products. So it shows that $40 \%$ of teenagers bargains and $38.3 \%$ teenagers bargains on highly prized products.

Relation of Price \& Quality.

\begin{tabular}{|c|c|c|c|c|c|}
\hline \multicolumn{2}{|c|}{ Options } & Frequency & Percent & Valid Percent & Cumulative Percent \\
\hline \multirow{4}{*}{} & Positive & 126 & 42.0 & 42.0 & 42.0 \\
\cline { 2 - 6 } & Average & 161 & 53.7 & 53.7 & 95.7 \\
\cline { 2 - 6 } & Negative & 13 & 4.3 & 4.3 & 100.0 \\
\cline { 2 - 6 } & Total & 300 & 100.0 & 100.0 & \\
\hline
\end{tabular}


The table no. 9 shows the relation of price of branded products with its quality, in which 126 respondents says yes that quality of branded products is positive to its price, and 161 respondents says average it means they said that quality is something better not impressive and 13 respondents says no they want to say that quality of branded products is worse than its price. So $50.7 \%$ teenage are averagely satisfied with quality of branded products relevant to its price.

Proportion used of branded \& unbranded.

\begin{tabular}{|c|c|c|c|c|c|}
\hline \multicolumn{2}{|c|}{ Options } & Frequency & Percent & Valid Percent & Cumulative Percent \\
\hline \multirow{4}{*}{} & $25: 75$ & 60 & 20.0 & 20.0 & 20.0 \\
\cline { 2 - 6 } & $50: 50$ & 167 & 55.7 & 55.7 & 75.7 \\
\cline { 2 - 6 } & $75: 25$ & 73 & 24.3 & 24.3 & 100.0 \\
\cline { 2 - 6 } & Total & 300 & 100.0 & 100.0 & \\
\hline
\end{tabular}

The table number. 10 shows that how much proportion of branded and unbranded products are used by teenagers, 60 respondents are using $25 \%$ branded products and $75 \%$ unbranded products, 165 respondents are using $50 \%$ branded and $50 \%$ unbranded products and 73 respondents are using $75 \%$ branded products and $25 \%$ unbranded products. It means that half of the teenagers $(55.7 \%)$ are using half branded products and half unbranded products.

Source of getting information

\begin{tabular}{|l|l|l|l|l|l|}
\hline Options & Frequency & Percent & Valid Percent & $\begin{array}{l}\text { Cumulative } \\
\text { Percent }\end{array}$ \\
\hline \multirow{3}{*}{} & Family Members & 108 & 36.0 & 36.0 & 36.0 \\
\cline { 2 - 6 } & Peers & 14 & 4.7 & 4.7 & 40.7 \\
\cline { 2 - 6 } & TV Adds & 82 & 27.3 & 27.3 & 68.0 \\
\cline { 2 - 6 } & Websites & 96 & 32.0 & 32.0 & 100.0 \\
\cline { 2 - 6 } & Total & 300 & 100.0 & 100.0 & \\
\hline
\end{tabular}

The table number.11 states that which source is used by teenagers for getting information about branded products, 108 respondents says that they get knowledge and information of branded from their families, 14 respondents says that the get information of branded products from their colleagues and peers, 82 respondents says that the get information by watching advertisements on TV and 96 respondents says that they get information from websites. It shows that mostly teenagers get knowledge from their family members and websites.

\section{Loyal customer.}

\begin{tabular}{|c|c|c|c|c|c|}
\hline \multicolumn{2}{|c|}{ Options } & Frequency & Percent & Valid Percent & Cumulative Percent \\
\hline \multirow{4}{*}{} & Yes & 177 & 59.0 & 59.0 & 59.0 \\
\cline { 2 - 6 } & No & 123 & 41.0 & 41.0 & 100.0 \\
\cline { 2 - 6 } & Total & 300 & 100.0 & 100.0 & \\
\hline
\end{tabular}

The table number.12 states that how many teenagers are loyal customers to the branded products, 177 respondents are loyal customers with the branded products and 123 respondents are not loyal to the branded products. So it shows that more than half teenagers in Hyderabad are loyal customers to the branded products.

Level of satisfaction.

\begin{tabular}{|l|l|l|l|l|l|}
\hline Options & Frequency & Percent & Valid Percent & $\begin{array}{l}\text { Cumulative } \\
\text { Percent }\end{array}$ \\
\hline \multirow{3}{*}{ Valid } & Highly satisfied & 80 & 26.7 & 26.7 & 26.7 \\
\cline { 2 - 6 } & Satisfied & 168 & 56.0 & 56.0 & 82.7 \\
\cline { 2 - 6 } & Neither satisfied nor dissatisfied & 34 & 11.3 & 11.3 & 94.0 \\
\cline { 2 - 6 } & Dissatisfied & 7 & 2.3 & 2.3 & 96.3 \\
\cline { 2 - 6 } & Highly dissatisfied & 11 & 3.7 & 3.7 & 100.0 \\
\cline { 2 - 6 } & Total & 300 & 100.0 & 100.0 & \\
\hline
\end{tabular}


The table no.13 states that how many teenagers are satisfied with branded products, 80 respondents are highly satisfied with branded products, 168 respondents are just satisfied with branded products, 34 respondents are those who are neither satisfied nor dissatisfied with branded products, 7 respondents dissatisfied with branded products and 11 respondents are highly dissatisfied with branded products. It shows $56 \%$ teenagers are just satisfied with branded products.

\section{Receive call/Message.}

\begin{tabular}{|c|c|c|c|c|c|}
\hline \multicolumn{2}{|c|}{ Options } & Frequency & Percent & Valid Percent & Cumulative Percent \\
\hline \multirow{4}{*}{} & Yes & 98 & 32.7 & 32.7 & 32.7 \\
\cline { 2 - 6 } & No & 202 & 67.3 & 67.3 & 100.0 \\
\cline { 2 - 6 } & Total & 300 & 100.0 & 100.0 & \\
\hline
\end{tabular}

The table number.14 shows that 98 respondents receive calls and messages from sales persons after purchasing branded products and 202 respondents don't receive calls and messages from sales persons after purchasing branded products. Mostly teenagers don't receive calls and messages from sales persons after purchasing branded products.

Usually purchasing from market.

\begin{tabular}{|c|c|c|c|c|c|}
\hline \multicolumn{2}{|c|}{ Options } & Frequency & Percent & Valid Percent & Cumulative Percent \\
\hline \multirow{4}{*}{ Saddar Market } & 75 & 25.0 & 25.0 & 25.0 \\
\cline { 2 - 6 } & Gul Centre & 85 & 28.3 & 28.3 & 53.3 \\
\cline { 2 - 6 } & Autobhan Road & 98 & 32.7 & 32.7 & 86.0 \\
\cline { 2 - 6 } & Others & 42 & 14.0 & 14.0 & 100.0 \\
\cline { 2 - 6 } & Total & 300 & 100.0 & 100.0 & \\
\end{tabular}

The table number.15 shows that 75 respondents usually purchase branded products from Saddar Market, 85 respondents usually purchase branded products from Gul Centre, 98 respondents usually purchase branded products from Autobhan Road and 42 respondents usually purchase from other markets of Hyderabad. It means that equal portions of teenagers purchase from different markets.

\section{Conclusion:-}

The above results show that all teenagers at least know the concept of branded and unbranded products. They have high preferences towards branded products because all respondents belong to Hyderabad city and economic condition of Hyderabad city is much better than other rural areas cities. Analysis shows that 59\% teenagers are loyal customers to someone brand, $74.3 \%$ teenagers say that they only focus on the quality of branded products when they purchase it. Whereas, $53.7 \%$ teenagers mentioned that quality of branded products is not enough good as compare to its price it means the average quality is offered by the branded outlets in Hyderabad city, the whole results shows that teenagers are quite enough aware about branded products and mostly female teenagers have more preferences than male teenagers because female teenagers showed interest and fill up questionnaires quite easily than male teenagers.

This research suggests that if companies target young adults through appropriate marketing strategy, it may enhance brand familiarity among young adults and profit of the organization. 


\section{References:-}

1. Shah, S. H. (2016). The Influence of TV Commercials on the Lifestyle of Youngsters. Bangladesh e-Journal of Sociology, 13(2), 156.

2. 35

3. Durrani, B. A., Godil, D. I., Baig, M. U., \& Sajid, S. (2015). Impact of brand image on buying behaviour among teenagers. European Scientific Journal, 11(5).

4. Grewal, D., Roggeveen, A. L., Sisodia, R., \& Nordfält, J. (2017). Enhancing Customer Engagement Through Consciousness. Journal of Retailing.

5. Harradine, R., \& Ross, J. (2007). Branding: a generation gap?. Journal of Fashion Marketing and Management: An International Journal, 11(2), 189-200.

6. Khan, I., Khan, I., Rahman, Z., \& Rahman, Z. (2016). Retail brand experience: scale development and validation. Journal of Product \& Brand Management, 25(5), 435-451.

7. Kotler, P., \& Keller, K. L. (2006). Marketing management 12e. New Jersey.

8. Lee Taylor, S., \& Cosenza, R. M. (2002). Profiling later aged female teens: mall shopping behavior and clothing choice. Journal of Consumer Marketing, 19(5), 393-408.

9. Martin, C. A., \& Bush, A. J. (2000). Do role models influence teenagers' purchase intentions and behavior? Journal of consumer marketing, 17(5), 441-453.

10. Mohtar, S., \& Abbas, M. (2014). Teenager's preferences and choice behavior towards branded or unbranded products. Journal of Business and Management, 16(7), 98-103.

11. Ross, J., \& Harradine, R. (2004). I'm not wearing that! Branding and young children. Journal of Fashion Marketing and Management: An International Journal, 8(1), 11-26.

12. Siddiqui, S., \& Singh, T. (2016). Social Media its Impact with Positive and Negative Aspects. International Journal of Computer Applications Technology and Research, 5(2), 071-075.

13. Teng, Laroche and Huihuang. (2007), The effects of multiple-ads and multiple-brands on consumer attitude and purchase behavior,:Journal of Consumer Marketing, Vol. 24/1, pp. 27- 